\title{
Politicking Ayurvedic Education
}

\author{
Anthony Cerulli \\ University of Wisconsin-Madison \\ acerulli@wisc.edu
}

\begin{abstract}
As the Indian population's interest in biomedicine increased at the end of the nineteenth century, public confidence in India's indigenous medicines flagged. Physicians of Ayurveda and officials of Indian medical organizations responded with discussions about and plans for reconfiguring the āyurveda ("life science") of the Sanskrit medical classics of Caraka, Suśruta, and Vāgbhața to be compatible with the anatomical, physiological, and pharmacological frameworks of biomedicine. This article considers some of the negotiations that shaped Ayurveda in late colonial and postcolonial India, paying special attention to how these debates affected the history of ayurvedic education. Reflecting on how the presence of biomedicine in India prompted ayurvedic practitioners to reimagine the history of their profession, it examines the revitalization of Ayurveda through the reinvention of ayurvedic education. It probes the historical move away from the gurukula as the seat of education and the institutionalization and standardization of education in the ayurvedic college. The historical record is expanded periodically with ethnographic data collected at gurukulas in South India to offer contemporary views on changes in ayurvedic education over the past 130 years. ${ }^{1}$
\end{abstract}

\section{Keywords}

Ayurveda - gurukula - India - history of medicine - history of education - colonialism

1 A note about the spellings and meanings of āyurveda, Ayurveda, and ayurvedic in this article: The word ayyurveda is a Sanskrit compound meaning "life science" or "knowledge for long life." It is therefore italicized and written with an initial lower case " $\bar{a}$." The term Ayurveda is a proper noun that has been absorbed in the English language lexicon, a title designating the classical Indian knowledge system that is based on the elaboration of ayurveda in the Sanskrit medical classics. It is thus written with an initial upper case " $\mathrm{A}$ " with no macron and 


\section{Introduction}

How and why did a centuries-old institution of Ayurveda, the gurukula-a Sanskrit compound meaning "teacher's household" - change from one of the tradition's centers of education to a site that was widely perceived as transmitting antiquated knowledge? With this question as its frame, the present study looks at the Ayurvedic Revitalization Movement-denoted hereafter by the abbreviation ARM - in late- and post-colonial India, when British-style colleges that combined ayurvedic and biomedical subjects supplanted the $g u$ rukula and its Sanskrit-based curriculum as the model for training ayurvedic physicians (vaidyas).

After centuries of gurukula-based education and healing, by 1947 India had 57 ayurvedic colleges, 51 ayurvedic hospitals, and 3,898 pharmacies dispensing remedies of Ayurveda and Unani. ${ }^{2}$ India's central and state governments built up an ayurvedic infrastructure in the 1950s and 1960s comprising British-style colleges, research centers, pharmacies, and hospitals, and by 1977 the Central Council of Indian Medicine (CCIM) held the authority to set a countrywide admission policy, syllabus, and exam structure for all vaidyas-in-training. ${ }^{3}$ Where and in what ways did Ayurveda's classical literary bases- the Sanskrit classics of Caraka, Suśruta, and Vāgbhața-belong in the new college curriculum? Historical events that changed how Ayurveda was taught, and in particular the passing of the gurukula as the tradition's foremost scholastic center, as well as noteworthy ideologues and organizations that conveyed the discursive fuel for change, lie at the heart of the present study. To supplement this history, I also occasionally allude to observations from my fieldwork at two ayurvedic gurukulas in central Kerala, Shantimana and Mookkamangalam. ${ }^{4}$

The article proceeds in five sections. Section I presents a quick overview of scholarship on the gurukula in the history of education in India, with special attention given to the gurukula in ayurvedic education. In section II,

not italicized. The term ayurvedic is treated here as the adjectival form of ayyurveda. When it qualifies a noun, it suggests the noun somehow relates to classical Indian life science (e.g., ayurvedic college, ayurvedic pharmacy, ayurvedic curriculum, and so on). It is not a proper Sanskrit word, but an English neologism. Hence it is neither capitalized nor italicized, and a macron is not placed over the initial 'a'. This last term is more expansive than the Sanskrit word āyurvedika, which is an adjective meaning "acquainted or familiar with āyurveda" and typically refers to a physician of äyurveda (that is, a vaidya).

2 Leslie 1963, 72.

3 Bode and Shankar 2017, 1 .

4 All personal names and place names having to do with my fieldwork have been anonymized in this article. 
I discuss the forms and functions of the Sanskrit medical classics in ayurvedic gurukulas in Kerala. I consider key people during ARM who transformed the public perception of the gurukula and the role of Sanskrit language and literature in ayurvedic education. Section III looks at the institutional contexts during the East India Company's rule in South Asia, which laid the groundwork for the integrationist agenda of ARM and the ascent of the ayurvedic college over the gurukula as Ayurveda's main educational center. Section IV explores some of the program's key spokesmen and organizations within ARM put forth to remedy what they saw as deficiencies in ayurvedic education and the practice of vaidyas. In the conclusion, section $\mathrm{V}$, I draw on my fieldwork in South India and reflect on conversations with recent graduates of ayurvedic colleges who opted to postpone the start of their professional careers to train at gurukulas. In view of the historical study, I discuss how questions and concerns debated during ARM simultaneously do and do not appear to be the intellectual patrimony of a new generation of vaidyas who receive training at both ayurvedic colleges and gurukulas.

\section{The Gurukula in Indian Educational History}

Scholarship on the forms and functions of the gurukula in the history of Indian education is rather limited. Studies of it in Ayurveda's history are equally slight, especially during the colonial period. Syed Nurullah and J. P. Naik's History of Education in India during the British Period is perhaps the most comprehensive study available today on Indian education under colonialism. ${ }^{5}$ The book is based on government policy records of education commission reports, acts, and charters, and it tends to present an overly tidy vision of India's educational past, painting Indian schooling as the product of a neatly dichotomous history in which schools were only "government versus private, indigenous versus Western and imperialist versus nationalist." ${ }^{\prime}$ Such binaries reflect a propensity among historians of Indian colonialism to see Western cultural institutions as "foisted on an unwilling South Asian people," as Projit Mukharji has observed of some existing histories of Indian medicine. Orderly colonized-colonizer dyads give the false impression that Western institutions were "closed systems" that were not open to influence from or exchange with local communities

5 Nurullah and Naik 1943 .

6 Basu 1982, 91. 
and peoples. ${ }^{7}$ But the expansion of colonial medicine in India did not simply establish closed medical systems that were imposed wholesale on local communities by Europeans. Diverse therapeutic perspectives and practices were often at play and in question among both colonial and Indian practitioners, the latter of whom were often associated with European physicians in one way or another, even if the power dynamic was ordinarily imbalanced, as section III below illustrates.

Notable studies of Indian educational history by N. N. Mazumder, R. K. Mookerji, and H. Scharfe offer sweeping portrayals of classical and modern education, relying on periodized views of India's past that reveal themselves to us today primarily in texts, and they give only fleeting consideration to the history of scientific education under colonialism. ${ }^{8}$ Aparna Basu's work, now almost half a century old, remains trenchant today for its probing questions and pathbreaking attempts at interdisciplinarity in the study of Indian education. In the early 1980 s, she commented that while historians frequently mention the gurukula's ubiquity in Indian antiquity, a sustained study of the gurukula and its pedagogical methods was lacking. ${ }^{9}$ Not much has changed between then and now. The present study begins to fill in some of the void in our understanding of the gurukula, its forms, and functions in Indian education. It builds on early studies by Charles Leslie and, more recently, Jean Langford, whose Fluent Bodies is an outstanding exception to the scarcity of research on the gurukula in ayurvedic education..$^{10}$ Langford's accounts of ayurvedic gurukula education in Haridwar are based on recollections of informants whom she interviewed in the 1990s about learning that took place in the 1930s and 1940s. Her interviews thus provide important data about the politics of the period when ayurvedic education was rapidly moving toward the college model that it has today, and they present special details about the legacy of this transformation in northern India.

The little research on gurukulas that has appeared over the past three decades tends to suffer in ways Langford's book does not: namely, knowledge production and transmission in the gurukula are blithely glossed as vestiges

Mukharji 2009, 76; 2016. To this end, Mukharji's work is influenced by, and indeed extends, the pioneering research of David Arnold on India's medical histories and, with respect to Indian history and science generally, of other members of the Subaltern Studies Group, writing anti-essentialist histories of colonial and postcolonial India "from below," such as Ranajit Guha, David Hardiman, and Gyan Prakash.

$8 \quad$ Mazumder 1916; Mookerji (1947) 1989; Scharfe 2002.

9 Basu 1982, 92; 1974.

$10 \quad$ Leslie 1963, 1968; Langford 2002. 
of India's hoary past; ${ }^{11}$ or gurukula culture is portrayed in ways that appear bizarre in view of my own fieldwork in South India and discussions with vaidyas and scholars today who have trained at gurukulas. ${ }^{12}$ Regional variations are to be expected in gurukula education, since languages of instruction vary from location to location, and often the particular texts, including vernacular sources on regional specialties, that a guru teaches differ from place to place. Indeed these regional differences are important. They speak to the multifaceted realities of Ayurveda, its multiple histories, and the various modernities that practitioners and patients of the tradition have always inhabited and promoted. Thus, in the following pages when I examine the history and abandonment of the gurukula as a visible center of ayurvedic education, consideration of Ayurveda's transformation on the lines of biomedicine is necessarily a layered discussion. Much of the historical survey between 1890 and 1977 depends on government committee reports and physicians' organizations that portray an imagined Ayurveda that was pan-Indian, whose practices were motivated by a singular ideology, and comparable to biomedicine. This layer of the conversation often resorts to broad strokes inclined to see Ayurveda as if it had been at one time, and could be in the future, a therapeutic system taught and practiced uniformly from Delhi to Kanyakumari, Bombay to Visakhapatnam, and everywhere in between. (In some ways, the CCIM's ratification of the ayurvedic college syllabus in 1977 reified that view.) As a consequence, regional particularities were ignored and local traditions based on gurukulas were overlooked. Ethnographic research at ayurvedic gurukulas in recent decades can muddy historical pan-Indian ideas of Ayurveda and its educational systems and suggest that efforts made in the nineteenth and twentieth centuries to make Ayurveda modern in a biomedical fashion, while certainly extensive and even popular, were not roundly hegemonic. The fieldwork I have done at South Indian gurukulas shows that local traditions have tried and, in some cases, been successful at resisting colonial and post-colonial pressures to translate

11 There are many examples of research portraying the gurukula as a symbol of the way things were done "in the past," à la Hardiman (2009, 274), which perpetuate the idea that Ayurveda's long-standing institutions and practices of education have not persisted into modern times. It is here that ethnographic research on Ayurveda can correct such assumptions contained in secondary literature on the historical record.

12 See, for example, Sivaramakrishnan's $(2006,71)$ depiction of ayurvedic gurukula training in North India as based not on a canon of texts and led by gurus who gain legitimacy and/ or notoriety for their ability to handle and comment on the classical literature, but on the quality of the guru's clientele. This portrayal doesn't jibe with my observations in South India, where guru-vaidyas often gain clientele on the basis of their educational pedigrees and acquire protégés precisely because of their abilities to comment on and extend the "big trio" (brhattraȳ̄) of Sanskrit classics for contemporary clinical use. 
their practices into methods and models that are biomedically intelligible. As I suggest in the conclusion of this study, ethnographic data contest scholarship that tends to view recourse to India's Sanskrit-inflected past by modern Indian intellectuals as, by default, nationalist and chauvinist.

It might be the case that gurukulas are sometimes referenced uncritically and at times misconstrued because the people writing about gurukulas haven't actually spent time at them. This may be because there are not many active ayurvedic gurukulas still operating today outside Kerala. ${ }^{13}$ Compared with other Indian states, Kerala's gurukula culture today presents ample opportunities to observe interactions between vaidyas and their students and patients. The textual bases of both education and healing at these sites are the Sanskrit classics of Caraka, Suśruta, and Vāgbhața (in Kerala Vāgbhața's Aștāingahṛdaya is by far the most widely used text). In the absence of participant observation, coupled with a shortage of scholarship on the institution in Indian history, generalizations, oversimplifications, and reconstructions befitting an imagined historical time tend to dominate writings on the subject.

\section{Transforming the Ayurvedic Gurukula}

The gurukula appears as a center of learning as early as the Upanișads; it is attested in Indian Buddhism, as well as Buddhist traditions beyond the subcontinent; and it's known in various forms of Tantra and Yoga. ${ }^{14}$ An inimitable kind of "school," gurukulas have had different forms wherever they have been. The ayurvedic gurukulas in North India recounted by Jean Langford's informants, for example, were brick-and-mortar schools with dozens of students and multiple teachers. Former students at these sites told Langford that they consisted of large student bodies under the guidance of a collection of gurus. ${ }^{15}$

13 A movement over the last forty years to preserve Ayurveda as it was practiced in the past has played out on a large institutionalized stage, ironically, where recent graduates of ayurvedic colleges can get a full gurukula experience in New Delhi's Rashtriya Ayurveda Vidyapeeth (RAV), which launched in 1988 and was funded by the Health Ministry's Department of AYUSH (an acronym for Ayurveda, Yoga and Naturopathy, Unani, Siddha, and Homeopathy). RAV's central mission is to "revive the traditional method of Gurukula system of informal education of India, e.g., Guru Shishya Paramapara," for recent earners of the BAMS degree granted at ayurvedic colleges. RAV claims to offer the opportunity to study with well-known vaidya-cum-Sanskrit scholars from all over India (http://www .ravdelhi.nic.in/).

14 Amila Joseph de Saram (2003) has provided a concise historical treatment of the Buddhist gurukula.

15 Langford 2002, 97-116. 
They don't describe an intimate pedagogical relationship like that imagined by the classical Sanskrit designation guruśisyasambandham, "teacher-student connection."

In most ayurvedic gurukulas, the Sanskrit medical classics are traditionally the basis for instruction and learning. These texts are designed to be studied and memorized from beginning to end, so that, if accomplished, a student (sissya) should become sensitive to an exhaustive array of associations between body, mind, and society that are thought to contribute to the production of disease and the maintenance of health. A student's teacher-the guru-should be the product of a similar education and have been treating patients for some time. The guru introduces the student to the Sanskrit classics, assisting him or her with memorization and interpretation of the texts. ${ }^{16}$ As recently as the mid-twentieth century, gurukula students were expected to know the Sanskrit language well enough by the end of a course of study to be able to apply lessons from the ayurvedic sources in their clinical work, often entirely from memory. The Aștāngahridaya is especially amenable to memorization, since it's composed of many pithy verses. Committing the text to memory gives a vaidya lots of flexibility when working with patients. Having internalized this storehouse of therapeutic knowledge, a vaidya can work across the text and its various sections (sthānas) and augment it with regional resources in ways that not only generate unique instantiations of ayurvedic practice but also, and more important, tailor remedies to particular clinical settings.

Variability in the outcomes of gurukula students' education is normal, since from one kula to the next curricula will vary depending on things like a guru's specialties, choice of texts and commentaries for study, and primary languages of instruction. In the last case, even though the root texts are the Sanskrit classics, a guru's commentary and conversations with students often occur in local languages. For example, when I first began visiting Mookkamangalam the gurus' lectures on the Aștāngahrrdaya and allied texts like the "collections" (saṃhitās) of Caraka and Suśruta, Rasaratnasamuccayah, and Tantrayuktih were primarily in Sanskrit, while lessons about regional therapies (e.g., "poison treatments", vișacikitsā), patient meetings, and any small talk were in Malayalam. What's more, even though Sanskrit and Malayalam texts structure the curriculum at this gurukula a "text" exists differently for gurus and students. For the guru, textual knowledge is orally revealed, unpacked, and analyzed. For most of the students, everything the guru imparts is received with paper-bound copies of the

16 Karin Preisendanz (2007) has written a thoroughgoing study of the guru's initiation of the ayurvedic student as it appears in the Carakasamhitā. 
text(s) being recited in hand, while many of them hurriedly jot notes in their margins. Very rarely today will a student at Mookkamangalam reach a level of fluency in either the Sanskrit or the Malayalam sources to be able to abandon cloth and paperback iterations of them. These textual bases are inexorably linked to the books they studied and used to take exams at college, whereas for gurus a text is something to be performed, something fluid and conversational, open to rearrangement and supplementation with other texts as clinical cases dictate. As I explain below, most students at Mookkamangalam nowadays (since about 2008) have recently graduated from an ayurvedic college, where they were wedded to physical books like any college student around the world (though of course this has changed with the ascension of e-readers). The point is that there is a stark contrast between oral and orthographic approaches to knowledge transfer and acquisition among gurus and students today, and this difference, I hope to show, is connected to the changes in ayurvedic education between 1890 and 1977 and the desuetude of the gurukula's Sanskrit-based training.

Historically, the educational activities of ayurvedic gurukulas in Kerala have occurred, as the name suggests, in the family houses of gurus. They typically have only one guru per house, and though there can be more than one student studying at a time, the one-on-one relationship between a student and his or her teacher is crucial for a successful education. It was common for students in Kerala up through the mid-twentieth century to attend more than one gurukula for different types of training. For example, the guru at Shantimana, Bhaskaran, had studied with different gurus for training in Sanskrit language and literature, English language and literature, the Yajur Veda, and other subjects in addition to studying in a gurukula with his paternal uncle, who trained him in the "family lineage" (paramparā) of "poison therapies" (vișacikitsā). When Bhaskaran learned the Aștāingahrdaya, he sat with his guru in a style that Malayalis refer to as mukhämukham, "face-to-face [learning]," that's been in practice in Kerala for centuries. I first witnessed this pedagogy on my initial visit to Bhaskaran's house in 2003. He was training his grandson, Biju, and a young woman, Latha. Today Biju and his mother continue teaching mukhämukham-style with their own pupils at Mookkamangalam, more or less following the teaching style Bhaskaran used with them, just as Bhaskaran's gurus did with him. ${ }^{17}$

17 The earliest textual sketch of what Malayali vaidyas describe as mukhämukham occurs in the Carakasaṃhitā (Sūtrasthāna, 30.16-19) - although the term itself is a Sanskritized Malayalam neologism. It is a three-part pedagogical method involving memorization and protracted scrutiny of an entire text. 
The gurukulas where Bhaskaran studied, the ones he directed, and those his daughter and grandson direct today are at once similar and different. There is a clear line of descent from teacher to student in each successive gurukula, naturally. But since each teacher is different, with different areas of interest, from one guru to the next variations emerge in such things as the texts that are taught and pedagogical techniques employed to teach them. Over time, this flexibility led to quite dissimilar programs of study within Ayurveda across India. This variation became a compelling feature driving people in ARM to push for educational unification beginning in the 189os, when the movement's spokesmen began suggesting practical means for vaidyas to legitimize their practices by making them more consistent with British colonial medicine.

By the last decade of the nineteenth century, ARM had crystallized into a nationwide effort, in large part thanks to the work of the Mumbai Vaidya Sabhā (Bombay Physicians' Society - hereafter MVs) and other physicians' organizations of Indian medicines, several of which, including MVs, I discuss in section IV. ${ }^{18}$ MVs's leadership created standards and structures for gurukula training and, eventually, paved the way for the college model to displace the gurukula as the operative institution for ayurvedic training. By 1890 Mvs leadership had concluded that "Ayurvedic study should be structured in a way that was appropriate to the time, in order to turn out skilled doctors who would be able to both promote Ayurveda and serve the public."19 MVs was responding to opinions within medical and governmental circles that viewed gurukula education as informal and lacking consistent goals. To bring structure to the education of vaidyas, Mvs founded two important institutions that set in motion a formal process of standardization in ayurvedic education: the Aryan Medical School and the Mumbai Āyurvedīy Pāțhaśāla. In 1907 the Mumbai Āyurvedīy Pāṭhaśāla initiated a curriculum for the All-India Ayurvedic Center for Scholarship (Nikila Bhāratīy Āyurvedīy Vidyāpīṭh), revised in 1908, which arranged a threetiered system of examinations for students training under gurus:

title 1: bhişak (physician), exams conducted in vernacular languages title 2: viśärada (adept), exams conducted in basic Sanskrit title 3: ācārya (preceptor), exams conducted in advanced Sanskrit

18 Throughout this article references to "Indian medicines" or India's "native" or "indigenous medicines" refer to Ayurveda and Unani primarily and their practitioners, vaidyas and hakims.

19 Mumbai Vaidya Sabhā 1990, 9; English translation is from Langford 2002, 103. 
MVs's efforts quickly influenced the education of vaidyas across North India, and ayurvedic (and other indigenous medical) organizations began adopting the same three examination ranks. The Âyurveda Mahāmaṇḍali (Great Council of Ayurveda) in Andhra Pradesh is usually recognized as among the earliest organizations to bring the Mumbai Āyurvedīy Pāṭhaśāla's curriculum to South India. ${ }^{20}$ Notably, in Mvs's charter to standardize the in-house, one-onone training that aspiring vaidyas had been receiving for centuries, the word "gurukula" was not used at the All-India Ayurvedic Center for Scholarship. Ratification of exams in the new guru-led lessons, which were totally foreign to the institution before 1908, initiated a process of transformation that would render the older system obsolete. The highest title, ācärya, continues to be used by the CCIM, whose syllabus names the ayurvedic college graduatethat is, a holder of the bachelor of ayurvedic medicine and surgery (BAMS) degree-an àyurvedācārya: "preceptor of Ayurveda."

Jean Langford has suggested that Mvs created the three-level exam system because, at the turn of the twentieth century, there was a lack of respect for Ayurveda among Indian nationalists, who publicly chided vaidyas for their lack of organization and failure to articulate this important Indian tradition's "unique connection to Indian cultural identity." MVs thus concluded that Ayurveda "could be promoted as one of the contents of national culture only if it were packaged in a standard institutional form."21 To that end, they emphasized Sanskrit at the second and third-level exams—viśärada and àcārya-to strike a cultural chord with the anticolonial nationalists, while the re-institutionalization of the gurukula in the forms of the Aryan Medical School and the All-India Ayurvedic Center for Scholarship marked a pivotal organizational development in education previously unseen. In both institutional structure and course of study, the gurukula curriculum began to look like the format of British medical colleges. At the time, Mvs maintained that Sanskrit language training still held a high level of symbolic import. The reality, however, was that as ayurvedic education moved away from the guru's kula and into buildings with lecture halls and labs, Sanskrit became a cultural symbol, laden with nationalist hues, more than a workable and rigorous language for therapeutic use. The lack of a genuine need for strictly imposed Sanskrit-based training of vaidyas consigned the gurukula to the dustbin of ayurvedic history. Langford's informants in Haridwar saw it that way — as the death knell of the gurukula in ayurvedic education - when they reflected on the founding of the CCIM and its subsequent systematization of the ayurvedic college syllabus in

$20 \quad$ N. Varier (1980) 2002, 476.

21 Langford 2002, 104. 
the 1970s, following decades of ARM's efforts to integrate the Sanskrit-based knowledge of the ayurvedic classics with biomedical edifices and categories. ${ }^{22}$

Some proponents of the agenda to integrate biomedicine and Ayurveda in the ayurvedic college curriculum argued that by reasserting and strengthening classical Ayurveda in the modern era, India might experience a kind of classical renaissance that echoed the days when India's religion was Hinduism and its preeminent science was Ayurveda. Their rhetoric resembled an earlier Orientalist idea that considered innovations in science and the arts as the hallmarks of all civilized societies. The idea that Ayurveda could be useful to modern Indians and germane to ongoing scientific discovery-by mixing European medicine and classical ayurvedic methods - carried the dual appeal of signaling a spiritual continuity with a glorious past while demonstrating the type of self-sufficiency, intellectual progress, and forging-ahead spirit that underlie every great civilization. This Orientalist platform, Charles Leslie claimed, forever altered traditional medical learning in India:

The leaders of the movement [i.e., ARM] adopted technology, ideas, and institutional forms from the evolving cosmopolitan system to found pharmaceutical companies, colleges, and professional associations, and to reinterpret traditional knowledge. They translated Sanskrit classics into English and vernacular languages, wrote manuals and modern textbooks for students, and published journals and popular tracts. They lobbied to create state and central government agencies that would support indigenous medicine. In short, the syncretism between Ayurveda and cosmopolitan medicine which anthropologists first noted in rural India in the 1950s was a far-reaching and long-standing aspect of Indian society, and it has greatly affected the ways that people interpret illness. ${ }^{23}$

The reach for Indian classicality offered a convenient ideological design for ARM to merge the old with the new. Yet, in an unstated and somewhat counterintuitive twist of intentions, the integration effort to preserve Indian classical medicine endorsed a vision of Ayurveda's foundation, its Sanskrit literature, that was hardly new. The proposal to bring together the best aspects of Western and Indian medical therapies under the curricular umbrella of Ayurveda was a tough pill to swallow for many, insofar as it was seen as watering down a knowledge system that was once effective on its own uniquely Indian terms. Even the most ardent supporters of integration recognized this. Opponents

22 Ibid., 106.

23 Leslie 1992, 179 . 
worried that Ayurveda would eventually become unrecognizable by the tradition's classical standards. We know well today, however, that the Sanskrit medical classics were anything but culturally insular discourses. They are products of an early Common Era cosmopolitanism in South Asia. ARM's integrationist urge to maintain the tradition was, in effect, motivated by a natural impulse to strengthen Ayurveda, not by closing it off to outside influence, but by inviting and acclimating scientific ideas and research methods that could augment and improve Ayurveda. In the early twentieth century, the transnational quality of Ayurveda's foundational texts continued to evolve and adapt to multicultural encounters with European biomedicine through integration. In the colonial context, however, this process was not satisfactory. Mixing the two medicines in the ayurvedic college curriculum was bound to appear to some as nothing less than the jettisoning of one of India's classical knowledge systems. In independent India, the conversation about embracing Ayurveda's past while preparing for its future was couched in both nationalist and globalist concerns.

As the days of the Raj became numbered and Independence inevitable, the politics of integrating Ayurveda and biomedicine garnered increasing governmental attention. In 1943 the British colonial government in India formed the Bhore Committee, a three-member task force headed by Joseph William Bhore (1878-1960), an Indian civil servant and diwan of Cochin State, with the mission of assessing the "real value" of India's indigenous medical systems and their treatment capabilities. In its final report in 1946, the committee declared it was unable to give an adequate assessment of India's native medicines, and it recommended that each state government be left to "decide what part, if any, should be played by the indigenous systems in the organisation of public health and medical relief." ${ }^{24}$ The Bhore Committee's original charge was unmanageable. India's medical landscape was diverse, as it continues to be today. Over and above the numerous regional kinds of the three premodern traditions of Ayurveda, Unani, and Siddha, there were (as there are today) other types of healing traditions, such as Yoga, Homeopathy, and numerous ritual or religious healers. Because of the many healing peculiarities on the subcontinent, Bhore's recommendation to divvy up assessments to each state thus appears to have been sound counsel.

Thirteen years after the Bhore Committee's work concluded, in 1958 the Government of India (GOI) appointed Katil Narasimha Udupa (1920-1992) —a surgeon, renowned advocate of integrative medicine and founding director, in 1960, of the Institute for Medical Sciences at Benares Hindu University — chair of the Ministry of Health's Committee on the Reform of Education, Practice 
and Research in Indigenous Systems of Medicine, also simply known as the Udupa Committee. In 1959, Udupa et al. offered an assessment of Ayurveda in the Udupa Report, which reflected fondly on the Bhore Committee for, along with taking on the laborious task of conducting a nationwide assessment of India's indigenous medicines, recommending the establishment of a chair of history of medicine in the All-India Medical Institute. This professor was tasked with the burden of studying "indigenous systems of medicine in view of the importance of investigating the extent to which they can contribute to the sum total of medical knowledge." ${ }^{25}$ In the same year as the final Bhore Report, 1946, India had its inaugural Health Minister's Conference, at which a boldly worded resolution was passed to ensure that state health organizations made provisions for training and research in Ayurveda and Unani. The resolution led to the formation of another committee in 1946, the Chopra Committee, headed by Ram Nath Chopra (1882-1973), an Indian medical service officer widely remembered as a pioneer in pharmacological research at the Calcutta School of Tropical Medicine. The so-called Chopra Report (shortened from "Report of the Committee on Indigenous Systems of Medicine"), issued in 1948, was the first thorough and geographically sweeping account of indigenous medicines in India. It promoted the need to advance an integrated biomedical-ayurvedic medicine in India, or what has been known colloquially since ARM as the "mixed Ayurveda" (miśra āyurveda) taught today at ayurvedic colleges. The Chopra Report's first two general recommendations were as follows:

[1] For rendering of medical relief, the Western and Indigenous systems should be harmonised.

[2] Synthesis of Indian and Western medicine is not only possible but practicable, though it will be time-consuming and not easy. Immediate steps should be taken in this direction. ${ }^{26}$

Integrationism continued to dominate the development of the ayurvedic college curriculum in post-Independence India. At one and the same time, integrationist discourse denied accusations of acculturating Ayurveda to biomedical standards and insisted that Ayurveda should adopt, where it benefited the Indian tradition, elements of biomedical science. ${ }^{27}$ With over a decade of distance from British colonial authority on the subcontinent, it's perhaps

\footnotetext{
25 Ibid.

26 Ibid. (emphasis in original).

27 Brass 1972, 371.
} 
unsurprising that the later Udupa Report in 1959 offered the following complex advice, striking a less obvious integrationist and more independent and nationalist tone. After recognizing the benefits of ayurvedic medicine all over the country for tens of millions of patients, Udupa et al. stated:

We do not believe, on the other hand in saying that there is no defect in the present practice of Indian Medicine or that practitioners of the system are up-to-date in their knowledge. But since its utility is well established, it is our duty and also the duty of the State to approach the problem with sympathy and encourage and recognise the system so that it can become more useful to the public. For carrying out all these programmes including research, a large number of men, money and material is no doubt needed. Let us give a full-fledged support and see the results, instead of blindly following and copying the methods followed by the United Kingdom and the United States of America. ${ }^{28}$

For the most assertive of ARM's integrationist organizations and spokesmen, gaining state support motivated their work. Without it, they thought Ayurveda was doomed to become one among many of India's classical successes turned into a modern casualty of colonialism. The Udupa Report's clear message to indigenous practitioners that independent India's government should support its native therapies with manpower and money must have rung forth a longhoped-for promise of recognition. The report's last charge not to follow blindly the United Kingdom and United States speaks to the enormous complexity that India's native medical traditions faced both during and after colonialism. For, from the $1890 \mathrm{os}$ on, Western medical standards of research and education using distinct biomedical disciplines became the indexes for Ayurveda to adopt in order for it to endure in the twentieth century. As a result, by the turn of the twentieth century and past Independence, ARM incorporated these integrationist measures in iterations of ayurvedic college curricula, ultimately solidifying them with the Indian Medicine Central Council Act of 1970 (Act 48), which enabled the GoI's Department of Ayurveda, Yoga and Naturopathy, Unani, Siddha, and Homeopathy (AYUSH) to form the CCIM in 1971. All the while, ayurvedic education was moving away from its textual foundations in the Sanskrit classics. The Udupa Report appears to suggest that moving into the 196os Ayurveda would do well to begin totally afresh, incorporating ways to train vaidyas and implement practices for this classical healing tradition based on standards and yardsticks crafted in India itself. The gurukulas of South 
India I have been visiting offer an insightful look at what that type of training and practice might have looked like. The ayurvedic college syllabus, conversely, which is highly unlikely ever to reverse its movement toward assimilation of global biomedical conventions, tends to reflect more of the symbolic spirit of Ayurveda as a premodern knowledge system than the literal letter of the tradition's premodern knowledge bases.

\section{ARM's Antecedents of Biomedical-Ayurvedic Integration}

Seeds of the ayurvedic college and ARM's integrationist agenda were sown before India came under the rule of the British Crown. Administrators in the East India Company (EIC) had introduced small measures to encourage collaboration between practitioners of biomedicine and Ayurveda. The Native Medical Institute (NMI) in Calcutta is the example of this affiliation most frequently cited by historians. Founded in 1822, NMI was an EIC-supported medical college designed, according to D. G. Crawford's History of the Indian Medical Service, to train doctors in a syncretic arrangement of Indian medical traditions and biomedicine, with classes held at the Sanskrit College for Ayurveda and the Calcutta Madrasa for Unani. ${ }^{29}$ Similar schools were proposed for Bombay and Madras. Optimism for the cooperative program lapsed after thirteen years, however, and in 1835 NMI was shuttered. The Civil Finance Committee in Bengal declared the institution a financial failure and its education inadequate, citing a lack of anatomical expertise in India's native healing traditions as a major deficiency in NMI's curriculum. ${ }^{30}$ The institution's collapse occurred amid EIC efforts to Anglicize education in India, a far-reaching process sternly captured in Thomas Babington Macaulay's "Minute on Education" on February 2, $1835 .{ }^{31}$ Essentially a language policy, Macaulay's "Minute" persuaded the British governor-general W. C. Bentinck to oppose the use of government funds to preserve Sanskrit and Arabic or allow vernacular-based instruction in schools and, instead, to start educating Indians using English in British-style institutions. The shift from Indian modes and institutions of learning to a British college model — with vice-chancellors, undersecretaries, and multiple faculty - had a profound influence on the subsequent history of Indian education. Surveys in the 1820s-30s suggest there was a desire for English education among the Indian population in the run-up to Macaulay's "Minute,"

29 Crawford 1914, 434.

30 Panikkar 1995, 150-51; Alavi 2008, 95; Bala 2014, 12-13.

31 Bureau of Education (1920) 1965, 107-17. 
especially among Indian leaders and elites who saw the English language as a key to the West. That desire notwithstanding, "the linguistic change-over in 1835 was astonishingly complete," Aparna Basu noted, and its impact was massive, with consequences that continued to unfold for decades..$^{32}$ Because it was deeply invested in Ayurveda's Sanskritic underpinnings, NMI floundered with an English-language curricular mandate. The institution might have "reflected the hybrid spirit of the early nineteenth century, where the veneer of cultural 'exchange' between Eastern and Western knowledge about medicine, disease and the body could legitimately characterize the venture," as Rachel Berger observed. But its "inquisitive and expansive liberal interest in multiple knowledge systems collided with a shifting imperial politic that privileged only one kind of learning for both Indians and Europeans alike."33 So, in 1835 governorgeneral Bentinck threw his weight behind Anglophone education in India, in the service of which NMI's closure was seen as a sizable and necessary exercise. In its place, he recommended the construction of a new medical college in Calcutta with a completely English-based curriculum. His express wish was that the new school's course of study distance itself from NMI's integrated syllabus and move toward educating aspiring physicians entirely in biomedicine. ${ }^{34}$

India's earliest biomedical schools-Calcutta Medical College (1835) and Madras Medical College (1835)-experimented with varieties of "bioindigenous" curricula, teaching Western sciences while acknowledging some therapeutic contributions of Indian medicines. These projects did not last long, and their syllabi quickly refocused on medical science as it was taught in Britain. The motivations of EIC administrators and physicians who earlier showed interest in Ayurveda and Unani eventually seemed contrived, if not duplicitous. Their support served their own practical needs rather than demonstrated genuine curiosity about the efficacy of Indian modes of healing. European doctors treated vaidyas and hakims as assistants, apothecaries, clinical technicians, and the like, but hardly ever as colleagues or collaborators. ${ }^{35}$ By the mid-nineteenth century, on the eve of the Raj, standard EIC policy did

\section{$32 \quad$ Basu 1974, 72.}

33 Berger 2013, 43-44.

34 Alavi 2008, 95-98.

35 Crawford 1914, 101-9. A well-known exception was the former NMI superintendent John Tytler, who attempted to persuade the Court of Directors of the EIC that the indigenous physicians at his institution were highly competent and, following NMI's closure, should be given new employment at Calcutta Medical College; the EIC Court of Directors dismissed Tytler's request and rejected his own application for the superintendentship of the new medical school. 
not allow Indian doctors to treat British employees if they hadn't received a minimal amount of biomedical training.

If in the first half of the nineteenth century biomedical physicians in India occasionally tried to learn about Indian medicines, and even enfold aspects of them into their clinical practices, from the 1860 s until the second decade of the twentieth century British administrators applied wide-ranging measures to manufacture biomedical hegemony on the subcontinent. ${ }^{36}$ Colonial doctors in the last half of the nineteenth century frequently called for strict regulations, and in some cases outright bans, on the practice of Ayurveda and Unani. ${ }^{37}$ Such demands reduced slightly after the Mont-Ford Reforms of 1919, which offered some, albeit limited, autonomy for provincial governments to manage the practice of indigenous medicines on their own terms. ${ }^{38}$ From the 1920 on, increased political support for homegrown therapies expedited the formation of advocacy groups to promote Indian medicines, such as the Board of Indian Medicine in North India's United Provinces. ${ }^{39}$ And yet, for many supporters of Ayurveda, the Mont-Ford Reforms ushered in a surprisingly dyarchic attitude in Indian society on the future sustainability and even necessity of Indian medicines. They discovered, Ralph Crozier observed, that "many Indian political leaders [were] no more sympathetic to the claims of Indian national medicine than the British had been." ${ }^{40}$ Some high-profile members of the Indian National Congress, including Mohandas K. Gandhi and Jawaharlal Nehru, downplayed Ayurveda as an insufficient and antiquated form of curative knowledge. Indeed, by the 1930s-40s "most Congress leaders were maintaining that the future health of India depended primarily on biomedicine." ${ }^{41}$ Between the 1860s and 1919, discussions about how to retool ayurvedic education took place in regional organizations like Mvs, Akhila Āyurvedīy Mahāsammelan (All-India Ayurvedic Congress), and Keralīya Āyurveda Samājam (Kerala Ayurveda Society) and were spearheaded by industrious vaidyas accomplished in both Ayurveda and biomedical sciences. In South India, as I explain below, the work of P. S. Varier, Ananthacharya Adya, and Divi Gopalacharlu, much

$36 \quad$ Kumar 1997 .

37 Arnold 1993, 59 .

38 The Mont-Ford Reforms of 1919, derived from the 1918 Montagu-Chelmsford Report, led to the Government of India Act in 1919.

39 Attewell 2014, 372; Hardiman 2009. Earlier examples were also seen in the princely states, such as Hyderabad, where in the 1890 s an administration for Unani and Ayurveda was created. But before the Mont-Ford Reforms, formal oversight of such operations was often absent (Attewell 2014, 373).

40 Crozier 1970, 283.

41 Hardiman 2009, 278. 
like the efforts of M. M. Gananath Sen in Bengal and others across northern India, actively contributed to ARM and Ayurveda's survival amid governmental cynicism about its value in modern India. ARM called for a thorough rethinking about, and reinvention of, the ayurvedic "tradition" that sought to formally integrate Ayurveda and biomedicine in an educational system designed to produce generations of vaidyas who could employ the two systems of medicine with equal agility. ${ }^{4}$

The development of the modern ayurvedic college syllabus-eventually born of the Indian Medicine Central Council Act of 1970 (Act 48), creating the CCIM and eventually granting this statutory body exclusive power to shape the course of study for all aspiring vaidyas in India—stands as the culminating feature of ARM's maturation. Today it is clear that ARM's integrationist agenda was successful at incorporating biomedicine into the ayurvedic college curriculum. My fieldwork at ayurvedic gurukulas in South India, however, also suggests that many graduates of ayurvedic colleges feel shortchanged by their BAMS degrees. For some of the doctors I've observed and interviewed, the combination of biomedicine and Ayurveda at the college level has produced cohort after cohort of vaidyas with mastery over neither Ayurveda nor biomedicine. Informants from South India regularly tell me they feel the BAMs degree has given them a basic, perhaps even solid, understanding of biomedicine; an Anglicized re-creation of classical Ayurveda; and only a titular appreciation for Sanskrit and the medical classics. For example, Shailaja Chandra's study, "Status of Indian Medicine and Folk Healing," cites a newly minted BAMS graduate who lamented that the ayurvedic college graduate "comes out almost empty handed at the end of the programme."43 For many young vaidyas today, discontent with their college training stems from the lack of serious Sanskrit studies on the BAMS syllabus. They view the Sanskrit classics-studied in the Sanskrit language - as the anchor that fixes them to their profession's tradition and, equally important, distinguishes this tradition from the biomedicine of Europe and North America. Without in-depth knowledge of these classical works in their original language, many of the BAMs holders I've met in India, though proficient in the "bio-Ayurveda" they learned at college, obtain their degrees disenchanted about the future of their practice vis-à-vis the tradition they opted to study.

This is not the case for most ayurvedic college graduates in India, however. "The irony of Ayurvedic education," Maarten Bode and Prasan Shankar recently wrote, "is that though there are around half a million [BAMS] graduates,

42 Langford 2002, 1-24.

43 Chandra 2011, 74. 
most of them practice biomedicine" after graduation. ${ }^{44}$ Unlike students I've met at Shantimana and Mookkamangalam, many ayurvedic college students and graduates in contemporary India had hoped to get into one of the highly competitive biomedical colleges in the first place but were unable to earn a seat. For these vaidyas the mixed syllabus of the ayurvedic college provides a backdoor entryway to practice biomedicine in some capacity.

\section{The Case for Integration}

The type of Ayurveda institutionalized today by the ccim syllabus is the product of ARM's many successes, failures, and compromises. Between 1890 and 1920 ARM introduced novel ways to represent and think about Ayurveda. But the movement was anything but univocal in its presentation. "Not a simple, linear isolated process of reviving a pristine, pre-colonial indigenous system," Uma Ganesan observed, ARM linked a network of people and organizations, many of which were involved with the (often Hindu-aligned) nationalist movements of the day. ${ }^{45}$ Those who advocated integrating Ayurveda and biomedicine found themselves caught in a knotty situation that demanded at once respecting and disparaging colonial medicine. It couldn't have been any other way. For the impressive growth of biomedicine in India by the beginning of the twentieth century forced indigenous medical practitioners to face the possibility of not only cooperating with colonial doctors but also considering workable means to combine their traditions with biomedicine for both clinical practice and education. According to Charles Leslie, vaidyas and hakims had no choice but to adopt the theories and instruments of Western science. They had to "do this while maintaining the appearance of loyalty to the categories of ancient [Indian] thought and humoral pathology." This exercise in cognitive dissonance, Leslie continued, "required monumental acts of self-deception."

Not everyone who saw the writing on the wall—viz., that Ayurveda in India was moribund in the twentieth century if its practitioners and educators didn't somehow adjust to biomedical standards and organization-thought ARM's only option was to take the path of institutionalized integration. At loggerheads were two broadly conceived camps of Indians "who thought traditional medicine could be modernized and those who did not." ${ }^{\prime 4}$ The smaller of the

\footnotetext{
44 Bode and Shankar 2017, 4.

45 Ganesan 2010, 121.

46 Leslie 1968, 570.

47 Crozier 1970, 283.
} 
two was a literalist camp bent on restoring a perceived precolonial śuddha, or "pure," Ayurveda from an imagined gilded classical era, a past that antedated Muslim and European colonizers in South Asia. This Ayurveda was developed and codified in the Sanskrit language shortly after the turn of the Common Era; it has been taught in gurukulas, traditionally, where students have received knowledge from experienced vaidya-scholars who both taught the classical literature, unpacking its sometimes cryptic tracts and complex theories, and demonstrated to their students how to use this knowledge to heal. The more sizable camp, however, accepted the proposal of combining Ayurveda and biomedicine. This position advocated for so-called miśra, or "mixed," Ayurveda.

In North India, a prominent ARM spokesman, prolific lecturer, and member of the All-India Ayurvedic Congress, M. M. Gananath Sen (1877-1944), crystallized the basic tenets of ARM in many public lectures and writings. He strove to illustrate publicly Ayurveda's timeless value in comments like this: "when the greater part of the world was submerged in ignorance, it is the Indian sages who first understood the necessity of dissection of the human body in the education of Physicians and Surgeons." ${ }^{\text {8 }}$ At the same time, Sen labored to prove the compatibility of Ayurveda's classical Sanskrit bases with Western scientific language and methods. When colonial authorities claimed not to understand or appreciate Ayurveda, Sen blamed Indian vaidyas for making confusion, not British and European newcomers to the region. For him, foundational theories of Ayurveda like the tri-doșa were analogical to, not incompatible with, biomedical theories. Whereas proponents of śuddha Ayurveda, like Sen's contemporary Shiv Sharma, vehemently resisted translating terms of the Sanskrit classics into English (e.g., doșa $\neq$ humor) -lest the capacious connotative power of Sanskrit to fuse both metaphysical and physical meanings in single ideas would be limited or lost ${ }^{49}$ - Sen explicitly offered English equivalents for Sanskrit terms and theories. For example, he declared that the doșa vāyu, typically called the "wind humor" in English, denotes the "functions of life as manifested through cell development"; pitta doșa is not the "bile humor," as it's often known but rather "the function of metabolism and thermogenesis"; and kapha doșa, instead of the "phlegm humor," is "the function of cooling and preservation (thermotaxis or heat regulation). ${ }^{50}$ The underlying message of Sen's work matched the message of most miśra Ayurveda supporters: to play a role in modern India, Ayurveda had to find a way to advance alongside and demonstrate its congruity with biomedicine.

\footnotetext{
48 Sen 1937, 11.

49 S. Sharma 1929, 175.

$50 \quad$ Sen 1937,13 .
} 
With the formation of the CCIM in 1971, a fixed nationwide syllabus for the BAMS degree was soon to follow. Just like the one in use today, it required students to study anatomy, physiology, and pharmacology, even though the Sanskrit classics do not delineate these independent divisions (much less "disciplines") as such. This is, of course, not to say that concern for the body, biology, and the actions of drugs are not fundaments of Ayurveda. Historically these topics were not (and still today are not) taught as independent units in ayurvedic gurukulas of South India, where the Sanskrit classics' organization of knowledge still holds sway. The topics are imbricated within a curricular logic that examines and explains health and sickness less by dividing up somatic branches of knowledge and more by teaching a layered epistemological method that is rooted in literature and meant for practice, such as the tantrayuktis ("text-methods"), which support a vaidya's identification and treatment of ailing bodies on the basis of not only the symptoms presented but also social and geographical factors. ${ }^{51}$ In the collegiate system that sprung up in metropolises during the Raj (by Independence there were fifty-seven urban schools),52 branches and subbranches of biomedicine were given Sanskrit names - for example, racanā śärīra vijñān, kriyā śärīra vijñān, and dravyaguna for anatomy, physiology, and pharmacology. ${ }^{53}$ Although the college courses were conducted in English and these Sanskrit-veneered subjects were inventions, doing this effectively brought biomedicine into the fold of Ayurveda's antique Sanskritic base. Translating English subject names into Sanskrit also gave biomedical terms an air of compatibility with Indian indigeneity and suggested a complementarity of the two traditions. ${ }^{54}$

In South India, ARM made several key advancements. In particular, I would like to look at three men whose productive careers launched physicians' organizations, research networks, and schools that concretized mixed Ayurveda across India's southern Indian states. Kerala lays claim to India's first ayurvedic college (āyurveda-pāthaśāla), the Ayurvedic College of Trivandrum, which was opened in 1886 by students of a famous Malayali vaidya, Paccumoottatu. ${ }^{55}$ From its inauguration this college experimented with a mixed ayurvedic syllabus. So, by the mid-189os when MVs and indigenous physicians' organizations across North India were advocating ARM's integrationist agenda, vaidyas in

\footnotetext{
$5^{1} \quad$ Mookerji (1947) 1989, 318-20.

$5^{2} \quad$ Leslie 1963,$72 ; 1968,569$.

53 Central Council of Indian Medicine (CCIM) 2011-12, 17-31.

54 Thatte and Tiwari 1980.

55 In a March 11, 2016 blogpost, Shailaja Chandra, former secretary of the Department of AYUSH, stated that the first ayurvedic college in India was established in Trivandrum (Thiruvananthapuram) in 1889: https://over2shailaja.wordpress.com.
} 
Kerala were already articulating best practices for miśra ayurvedic education as it moved into the next century. ${ }^{56}$

Few leaders contributing to ARM's efforts not only in the south but nationwide matched the efforts of Kerala's P. S. Varier (1869-1944). As a youth, he studied Ayurveda in a gurukula with the famous Nambūtiri aștavaidya Kuttanchery Vasudevan Mooss, and by age seventeen he had also been trained in biomedicine (or allopathy, as it's frequently called in India). At age thirty-three, in 1902, in the town of Kottakkal he developed the famous Ārya Vaidya Śāla, a pharmacy that since its inauguration has been the touchstone for ayurvedic pharmaceuticals in India and abroad. ${ }^{57}$ That same year, with a cadre of Malayali vaidya-activists, Varier was instrumental in securing financial backing from the zamorin of Calicut, Manavikrama Ettan Raja, to establish the Ārya Vaidya Samājam, which provided traditional gurukula instruction and clinical care, at Ārogyacintamani, the pharmacy of Vellanisheri Vassunni Mooss in Chalappuram. In 1913 the samājam was renamed Keralìya Âyurveda Samājam, with Varier as the society's director. ${ }^{58}$ He was outspoken about the need to improve ayurvedic education and eliminate negligence among vaidyas in his home state, and he was a champion of so-called Kerala Ayurveda, always highlighting the state's unique therapeutics and materia medica. To ensure that vaidyas were being trained according to his own high standards, in 1917 he founded the Āryavaidya Pāțhaśāla in Calicut and financed it with resources from his pharmacy in Kottakkal; in 1924 he moved the päțaśála to Kottakkal, renaming it Vaidyaratnam P. S. Varier Ayurveda College. He connected a charitable hospital to the college in Kottakkal, which today is affiliated with the University of Calicut and regarded as one of the premier ayurvedic colleges in India. Like several of the founding vaidyas of Mvs, to which I return below, ${ }^{59}$ Varier is remembered in Kerala and throughout India today as a key figure, a

$56 \quad$ N. Varier (1980) 2002, 504 .

57 Ibid., 505; Chattopadhyay 2002, 1500-1501.

58 Also at this time, its location was moved from Chalappuram to Cheruthuruthy, situated centrally between the princely states of Kochi and Malabar, where India's first public ayurvedic hospital is reputed to have opened on the banks of the Bharatapuzha River. A history of Kerala's early twentieth-century ayurvedic samājams is provided at www. samajam.org.

59 The Mumbai Vaidya Sabhā’s 125-year (1890-2015) anniversary volume, Śatakottara Rajata Jayantī Samäroha Samiti, lists the following eight physicians as taking part in Mvs's inauguration: Dr. Annāsāheb Moreśvar Kunțe, MD; Dr. Bhālacandra Kṛ̣ṇa Bhāțavaḍekar; Vaidyarāja Śrī Śañkaradājī Śāstrī Pade; Vaidyarāja Jațāśan̉kar Vițthaljī; Dr. Kher; Vaidyarāja Vāsudeva Śāstrī Enāpure; Vaidyarāja Kānajī Kevalarām; Vaidyarāja Mūlaśańkar Purușottama (Mumbai Vaidya Sabhā 2015, 12-14). 
"critical insider" as Gita Krishnankutty called him, within the ayurvedic community who helped "save" the tradition from becoming an outdated relic in modern India. Because of his erudition and wide-ranging medical interests, his message of reform made sense to Indians and non-Indians alike. He had the acuity to identify aspects of Ayurveda that were failing and the wherewithal to cultivate resources to rejuvenate the tradition by "integrating it with western epistemology" in language that portrayed Ayurveda as a sine qua non for Indian character and culture. ${ }^{60}$

In Karnataka at the end of the nineteenth century, Mysore's Indigenous Hospital, established in 1892, dispensed both ayurvedic and Unani medicine. Received positively at first, in time the hospital's efforts to promote healing and education based on India's indigenous medicines were overcome by demands from the government to be more progressive. This basically meant that the hospital needed to adopt an "integrated approach" that "would produce an 'indigenous' medicine aligned with disciplines of modern medicine." ${ }^{1}$ To this end, Ananthacharya Adya (1883-1968?) was an important Kannadiga integrationist who helped to systematize Ayurveda. He was one of the founders and a former president of the Nikhil Karnataka Āyurveda Maṇdala (All-Karnataka Ayurveda Constituency), which promoted India's indigenous therapies, chiefly Ayurveda but also Yoga, by ensuring that these curative systems adhered to Western scientific standards. Adya published a Kannada version of the ayurvedic journal started by P. S. Varier, Dhanvantari, and he translated the Sanskrit classics into Kannada. Later, in 1954, he founded an ayurvedic college and the Nutan Ayurvedic Pharmacy at Bijapur. ${ }^{62}$

Born in Masalipatam, Andhra Pradesh, Divi Gopalacharlu (1872-1920) was a student of Ayurveda at Mysore's Sanskrit College in the 1890s. He traveled widely in India, observing and taking copious notes on the different types of ayurvedic practice and research carried out across the country, before becoming the resident physician of the Theosophical Society of Bangalore. He made his name at the end of the nineteenth century by creating and manufacturing two botanical remedies-haimadi panakam and satadhouta ghritam-which are said to have saved countless people from death during the great plague that ravaged Bangalore in $1898-99 .{ }^{63}$ Gopalacharlu set up an ayurvedic research lab and pharmacy in Madras, the Āyurvedāśrama, that became a central place for

\footnotetext{
6o Krishnankutty $2001, \mathrm{ix}-\mathrm{x}$.

61 Attewell 2014, 375.

62 Chattopadhyay 2002, 13.

63 Ibid., 482; Attewell 2014, 377-78.
} 
testing the efficacy of ayurvedic drugs (many of which were shipped to him from all over India). His lab looked for concrete evidence that the Sanskrit medical classics contained rigorous and valid therapeutics comparable to biomedicine. ${ }^{64}$ Gopalacharlu and his team were careful to present the foundations of Ayurveda in English terms without resorting to technical Sanskrit jargon. This tactic tended to engage rather than alienate European doctors, and it opened up space to make the case that Ayurveda could be rendered intelligible and shown to have methods of bodily investigation and knowledge on a par with Western medical ideas. As Guy Attewell put it, Gopalacharlu's "institutions and innovations stood for 'progressive' ayurveda, a modernity for ayurveda which recognized the values of western medicine but was not subordinate to it, if anything its claims were superior." ${ }^{\prime 65}$ Always trying to represent Ayurveda as biomedicine's equal—an approach Charles Leslie famously called self-deceptive-Gopalacharlu echoed the discursive posturing of many contributors to ARM like Bhagvat Sinhji, Gananath Sen, P. S. Varier, and others who struggled to oppose (if only symbolically) medicine that arrived in India from the West, while at the same time working to professionalize vaidyas according to biomedical standards. Unlike some of his integrationist peers, Gopalacharlu's legacy is also philanthropic: he left a generous amount of money in his will to fund university chairs in Ayurveda and scholarships for students at government ayurvedic colleges in Mysore and Madras. ${ }^{66}$

If spokesmen like Sen, Varier, Adya, and Gopalacharlu provided the discursive grist for ARM's efforts, the movement's millwork was often carried out by professional organizations that could leverage their cultural and political heft to introduce changes in ayurvedic education. As I have already noted, apart from the societies with which each of the foregoing men were involved, Mvs, formed at the start of ARM in September 1890, was fundamental in shaping public reception of Ayurveda and institutionalizing its education as a collegiate system as the nineteenth gave way to the twentieth century. Modeled like a British colonial organization, Mvs had an elected president and two undersecretaries. It mobilized physicians in India, especially in Maharashtra, Gujarat, and Kerala, to form biomedical-style pharmacies, hospitals, and colleges. It took a consistently hardline integrationist stance, claiming that total opposition to the supremacy of colonial medicine, which had, in Madhuri Sharma's words, "the moral and economic force of imperialism with it," was

\footnotetext{
64 Srikanta Murthy 1968, 90-91.

65 Attewell 2014, 378.

66 Ibid., 378-79; Srikanta Murthy 1968, 91.
} 
futile. ${ }^{67}$ The economic force and moral dynamism of biomedicine during the Raj had, by the end of the nineteenth century, already won over many Indians, who at the time accepted and expected Western models and standards of sanitation, vaccination, and health care and had begun to assess the customs and practices of India's native medicines disapprovingly. Mvs's efforts to assimilate curricular aspects of biomedicine in the educational ambit of Ayurveda were critical in managing a worsening popular opinion of vaidyas, who since the 186os were regularly condemned as quacks by colonial administrators and doctors. In 1907 MVs helped form the All-India Ayurvedic Congress, which rapidly became, and remains today, one of the most influential ayurvedic associations in India. ${ }^{68}$

Despite ARM's many successful integrationist efforts to ensure a viable future for Indian healing traditions, in 1912 indigenous practitioners endured a significant setback in their ability to practice medicine without government penalty. That year the Bombay Medical Registration Act passed, reviving a similar proposal from 1909. The effect of the act on the state of indigenous medicines in colonial India, K. N. Panikkar wrote, was devastating:

Apart from constituting a medical council, the Act provided for the registration of medical practitioners. Only those who were registered under the Act were now to be considered competent to issue medical certificates or eligible for appointment to public offices. The registration was open only to "Doctor, Bachelor and Licentiate of Medicine, and Master, Bachelor and Licentiate of Surgery of the Universities of Bombay, Calcutta, Madras, Allahabad and Lahore and holders of a diploma or certificate from a government medical college or school." The Act thus constituted a body of "legally qualified medical practitioners" exclusively trained in western medicine. ${ }^{69}$

The act delegitimized the practice of Indian medicines and thus barred indigenous practitioners from state support. This was alarming for some in ARM, who cited the lack of state support to explain Ayurveda's fall into disuse during the medieval period, when the so-called Muslim medicine Unani rose in prominence alongside the ascendancy of the Delhi Sultanate in the thirteenth century and subsequent Indo-Persian cultural expansion during the

67 M. Sharma 2012, xi.

68 Langford 2002, 103.

69 Panikkar 1995, 149. 
Mughal Empire. ${ }^{70}$ While the act didn't ban the practice of Indian medicines outright, barring these healing traditions from state sponsorship occluded their opportunity for official legal approval. The timing was also unfortunate. Because the act appeared when India's indigenous physicians were working to reverse their increasingly negative public reputations, its effect on popular confidence was seen as potentially ruinous.

After the Bombay Medical Registration Act was passed, many vaidyas felt that in time administrative actions would become more aggressive and completely outlaw the practice of indigenous medicines (a measure that had been proposed fifty years before by an early-Raj administration). Despite oratorical rancor among devotees of pure Ayurveda (śuddha āyurveda), the act was a clear sign that integration was inevitable. K. N. Panikkar reminds us that ARM progressed by "opposing the cultural ambience created by colonial medicine" while at the same time "incorporating elements of western knowledge perceived as superior and yet undeveloped in the indigenous system."71 Accordingly, even while some felt "so marginalized that they sought survival more in resistance than in collaboration," Deepak Kumar has shown that most Indians felt that "total acceptance of new knowledge did not mean total rejection of the old and favoured a new synthesis of western and indigenous medical systems."72 If ARM was going to grow and earn government support for its schools and practitioners, three broad problem areas were quickly highlighted as crucial to fix.

First, ayurvedic physicians were widely perceived as unskilled. At the beginning of the twentieth century, vaidyas were seen as amateurish and unaware of the knowledge contained in the Sanskrit medical classics-knowledge, paradoxically, that by itself was gradually becoming regarded as insufficient for competency as an ayurvedic physician. In 1916 P. S. Varier spoke to the need to reform Ayurveda in a biting editorial, "Āryavaidyapariṣkāraṃ" (Reform of the noble medicine), in the Malayalam ayurvedic journal, Dhanvantari, that he had founded in Kottakkal in 1903 with his cousin, P. V. K. Varier. "The noble medicine must update" (äryavaidyatte parișkarikkanam), he powerfully begins the piece, and moves on to say that vaidyas of his day were not as skilled in Sanskrit language and literature as they were in previous generations. Many were ignorant of ayurvedic theories and methods, he argued. Consequently, they circulated prescriptions that were poorly prepared, often borrowed, composed of unknown or inadequate substances, and they dispensed them

$70 \quad$ Sinhji (Sinh Jee 1896) 1981, for example, expressed this position clearly and vociferously.

71 Panikkar 1995, 174-75.

72 Kumar 1997, 186. 
to unsuspecting patients. He thought that vaidyas, contrary to the tenets of the Sanskrit classics, had become moneygrubbers, not healers, and thus, the Indian population had every right to dismiss Ayurveda as illegitimate if its practitioners continued down their then-current path. ${ }^{73}$

Second, the materia medica needed to produce first-rate ayurvedic drugs were of low quality or unavailable. The 1923 Usman Report of the Madras Government Committee on the Indigenous Systems of Medicine directly addressed this matter. In the report, Muhammad Usman et al. described a scenario in which a lack of state sponsorship had greatly hindered the ability of vaidyas and ayurvedic pharmacists to cultivate, mix, and disseminate highquality medicines. At the same time, rapidly expanding state-supported biomedical dispensaries outshined ayurvedic pharmacies and took away much of their business. ${ }^{74}$ In South India, P. S. Varier's earlier pharmaceutical project, Ārya Vaidya Śāla, experienced similar problems, anticipating the Usman Report's bleak outlook for the future production and manufacture of ayurvedic drugs. Varier worked with special herb collectors and growers to procure the best available ayurvedic remedies in Kerala. But rapid development in Kerala and in the neighboring states of Karnataka and Tamil Nadu destroyed many of the plants Varier insisted were necessary to produce the best drugs. So, in 1934 he set up a 115-acre garden thirty kilometers from Ārya Vaidya Śāla to produce the plants he needed. This garden continues to supply the pharmacy with over four hundred botanical varieties that go into the dispensary's pharmaceuticals, all of them carefully cultivated according to Varier's initial instructions. Today Ārya Vaidya Śāla's medicines are widely acknowledged as the most reliable and consistently manufactured ayurvedic pharmaceuticals in India, and they are shipped all over the world. ${ }^{75}$

Third, the educational system of Ayurveda was considered to be outdated, ineffective, and far too reliant on the Sanskrit classics to be relevant in the modern era. To standardize and institutionalize integrated Ayurveda in the twentieth century, the two-thousand-year-old gurukula model of education needed to be replaced by British-style colleges for training vaidyas. In contrast to the gurukula's use of the Sanskrit classics for education and treatment, ayurvedic colleges were designed to be suppliers of a modern medical science that was equally indigenous and precolonial as well as cosmopolitan and competitive. What many vaidyas and students at colleges and gurukulas today often think of

73 P. Varier 1916.

74 Usman et al. 1923, 5-10.

75 в вС World made a documentary about the Ārya Vaidya Saala in 2013 that delves into some of the history discussed here. 
as the "tradition" of Ayurveda is associated with the Sanskrit medical classics. Gurukulas in Kerala continue to teach and use them to treat patients, whereas a detailed philological mastery of Ayurveda's classical literature, even of just one of the Sanskrit classics, has not been a requirement on the ayurvedic college syllabus since the CCIM engineered it in the 1970s. Instead, the integrative curricular agenda at ayurvedic colleges has retained the classics as symbols of India's premodern scientific virtuosity, and therefore teaches them more as history (itihāsa) than as practical resources for everyday consultation and clinical practice, as they are employed at gurukulas in South India.

\section{Ayurvedic Integrationism Today}

Thus far, this study has focused primarily on the past. In a sense, the preceding historical considerations developed out of an attempt to make sense of what I have been seeing in the field among vaidyas in South India since 2003. What began as an ethnographic project intended to describe and analyze the "practice of texts" in contemporary Ayurveda - that is, to explain what ayurvedic physicians in South India do with classical texts when training physicians and treating patients-interconnected with a study of the role of Sanskrit studies at ayurvedic colleges and gurukulas and then led me to the political foundations of the present ayurvedic college syllabus in India. To conclude, I would like to reflect on my conversations with vaidyas and students primarily from Kerala, Karnataka, and Tamil Nadu, which directed me to this historical study. If, as I hope, archival resources illuminate the colonial and postcolonial past of ayurvedic education, fieldwork can illustrate how traditions are formed in the nebulous spaces of national and local memories and how these memories suggest that people always inhabit multiple modernities as they bring events of the past to bear on the present.

Because training in the Sanskrit medical classics has all but vanished from the ayurvedic college syllabus, many gurukula students I have met in South India say that studying the Sanskrit works of Caraka, Suśruta, and Vāgbhața in a traditional setting and manner-"face-to-face" (mukhāmukham) with a guru, buoyantly re-creating the gurusisyasambandham of yore-can rectify what they consider to be a gap in their medical knowledge. The CCIM's nationwide syllabus retains a nominal place for Sanskrit in the ayurvedic college curriculum to underscore the tradition's origin in premodern India-regardless of the minimal extent to which the language is actually studied in the course of acquiring a BAMS degree. To illustrate the lasting impact of ARM's integrationist developments in the nineteenth and twentieth centuries, while on a 
field visit to Mookkamangalam in 2013, three students told me a story about an extreme case in 1997-98, when the Sanskrit exam and the required one hundred hours of Sanskrit coursework on the syllabus were suspended at an ayurvedic college in Karnataka. Evidently in response to students' objections to the Sanskrit requirements, the college's administration concluded that the Sanskrit exam and coursework were excessive because Sanskrit was a "nonmedical subject," and they removed the requirement. The decision was well received by most students ... until graduates tried to register as doctors with the Karnataka State Ayurveda and Unani Practitioner's Board, which refused to acknowledge their degrees because they had not taken the Sanskrit exam on the BAMs syllabus. The rebuffed students protested, ultimately influencing a senior member of the Karnataka Legislative Assembly, who opened an investigation into the matter. The college eventually agreed to conduct separate exams in Sanskrit for the students affected by the blunder; marks were retroactively added to transcripts; and the BAMs graduates were properly registered with the Practitioner's Board. Whether this incident in Karnataka was an isolated event, or even if in fact it occurred in the way it was reported to me, I have yet to determine. ${ }^{76}$ And though I have heard stories of other ayurvedic colleges doing similar things, the Karnataka case points to a truth and, perhaps more important, a perception about a truth regarding the place of Sanskrit in ayurvedic education today: serious study of Ayurveda's classical literature has greatly attenuated in India's ayurvedic college system, and many on the administrative and student side of the issue do not see this as a problem.

This is not to say that attempts to give mixed Ayurveda a Sanskritic façade haven't occurred. The first half of the twentieth century witnessed occasional efforts to "Sanskritize" biomedical literature and subjects for inclusion in the ayurvedic college curriculum. P. S. Varier's Brhaccārïram (Great Body, 1942-69), is a well-known example of European ideas about anatomy translated into Sanskrit. Gananath Sen's 1911 publication Pratyakșa-Śārïram (Perceptible Body), which likely inspired Varier's work, was designed to be an anatomy textbook on the syllabus of the All-India Ayurvedic College that organizations like the Mvs and the All-India Ayurvedic Congress (founded in 1907 in Allahabad) strove to build. ${ }^{77}$ Presenting like a translation of Grey's Anatomy from English into Sanskrit, Sen's project regarded Ayurveda as "Hindu medicine," and he took it upon himself, using his own money, to advance ARM by promoting the integrationist agenda without apologizing for the alterations to the Sanskrit medical

76 Though at least four other people I asked about this story confirmed its veracity, at present I have not been able to find any solid evidence of the story in print.

77

Berger 2013, 6o. 
classics that ensued. The presence of Sanskrit in his textbook conveyed a great deal: it was homegrown and precolonial, even if the content conveyed by the language was not part of the classical Indian knowledge system it appeared to be on the surface. Though in the end the textbook was controversial and never attained wide readership, Sen envisioned the project to be proactive and constructive. ${ }^{78}$ Sen's aims, presented in the introduction to Pratyakșa-Śärîram, are nothing if not lofty. He proclaimed that educational reform would contribute to the "welfare of the people," neither capitulating to nor retreating from biomedical influence on the subcontinent. ${ }^{79} \mathrm{He}$ imagined that he was writing a future for ayurvedic education in his homeland's own language, while utilizing biomedicine as a major foundation for moving forward.

Scholarly and popular discussions about how the Sanskrit language has been used in India since the early nineteenth century are often fraught because of the near-complete appropriation of the Sanskrit tradition by Hindu fundamentalists. ${ }^{80}$ In this milieu, to oppose Sanskrit and the political implications it represents is to object to communal orthodoxy, insularity, and attempts to create an Indian nation characterized by Hindutva, or "Hinduness." The nationalism of Hindutva groups is a dangerous ideology of marginalization that has frequently incited violence. The complex history of tradition-making in Ayurveda-from ARM, to the CCIM's ayurvedic college syllabus, to the current education of young physicians at gurukulas in South India-is marked by successes won alongside and in the wake of Indian nationalist and Hindu revivalist movements in the nineteenth and twentieth centuries. For different reasons at each stage in this history, as Simona Sawhney noted of modern intellectuals and writers who have used Sanskrit to highlight the political import of their work, "we detect that the turn to Sanskrit texts was perceived as a necessary task, even a culturally and politically urgent one." ${ }^{81}$

While arduous study of Sanskrit language and medical literature on the ayurvedic college syllabus has, as I have argued, become a symbol of India's venerable medical history and achievements more than an operative language of texts that carries workable knowledge, my fieldwork suggests that for some vaidyas it also exists otherwise. Students and gurus who spend intensive periods of time philologically engaged with the collections of Vāgbhața, Caraka, and Suśruta - continuing what during ARM and after has been characterized as pure Ayurveda (śuddha àyurveda)—study and memorize these texts for

\footnotetext{
78 Chattopadhyay 2002, 1248.

79 Berger 2013, 60.

8o Sawhney 2009, ix.

81 Ibid., 15 .
} 
their usefulness as manuals to learn and improve their clinical practice. On this point ethnography offers a noteworthy counterpoint to the historical record of revitalization and integration. However the Sanskrit literature is deployed, as a cultural icon or as a direct conduit for healing, we might recognize its use as a type of activist negotiation of the inheritance of biomedicine in India. This point is routinely overlooked in scholarship on colonial Indian medicine by scholars who liberally, and I think sometimes unreflectively, apply the labels of national chauvinism and fundamentalism to any and all efforts of ayurvedic physicians to connect the past, especially a past encapsulated and represented by Sanskrit literature, with contemporary therapeutic practices.

For promoters of medical integrationism (miśra āyurveda) in the last decade of the nineteenth century, as well as for federally unaccredited gurus and vaidyas at gurukulas in South India who for the past three centuries (or more) have adhered to a largely "pure" curriculum based on theories and practices set forth in the Sanskrit classics, the cosmopolitan encounter with biomedicine helped them achieve important goals. Integrationists eventually gained full backing under the independent GOI, and today India lays claim to nearly $35^{0}$ ayurvedic colleges and many more ayurvedic hospitals and pharmacies. ${ }^{82}$ Practitioners at gurukulas like Shantimana and Mookkamangalam cannot claim achievements on a par with integrationists. But they have continued their educative and clinical practices relatively unimpeded, seeing patients of all classes, castes, and religions. In so doing, some of them have created reputations garnering the attention of patients, scholars, and physicians across India and around the globe. Both groups represent elements of the multiple modernities and traditions of Ayurveda today. Proponents of both "pure" and "mixed" Ayurveda, as well as those who do not adhere to either camp exclusively but are influenced by both, continually impress "new points of inflection [on present-day Ayurveda] by demanding that it deal with new actors, new operations, and unprecedented and flexible forms of accumulation." ${ }^{83}$ Students who study at gurukulas in Kerala, in addition to receiving BAMs degrees, view both sites of their education as critical to the modernization of Ayurveda in ways that are commensurate with the tradition's classical past and in step with the multinational world in which they currently live.

An active incorporation of a premodern Sanskrit knowledge system in a contemporary worldview and practice entails a process of activist reading of one's tradition. It requires that one read old texts while self-consciously keeping potential ends of that reading in play in the present. This type of hermeneutic

82 Varma 2015, 142.

83 Diouf 2002, 127. 
method can have (and has had) devastating consequences, to be sure (the razing of the Babri Masjid in Ayodhya in December 1992 readily comes to mind, to cite one well-known example). Simona Sawhney's thoughtful study of the various uses of Sanskrit in modern India in the work of people like Tagore and Gandhi, however, suggests that activist uses of Sanskrit literature, especially when they do not disregard "the letter of the text in pursuit of action and the truth," are also tremendously important "in the context of contemporary India, where the fate of the present seems to be inescapably linked to available readings of early texts." ${ }^{4}$ We must be careful, Sawhney warns, not to always see dependence on historical knowledge in the present as automatically antimodern, nationalistic, anticosmopolitan, and dangerous. It has been those things in India (and elsewhere). But sometimes this type of reading is off the mark and misunderstands and mischaracterizes certain groups' engagements with their pasts.

Many of the students and gurus at gurukulas I have observed in Kerala, for example, may indeed be activist readers. They participate in an ongoing intellectual exchange that is not captured by notions of pure or mixed Ayurveda that arose under colonialism. One could reach back further than the British, of course, to illustrate the point that mixed or cosmopolitan medicine in India is old news, citing transnational medical encounters in India in which Ayurveda was equally influenced and influential, such as Hendrik van Reede's seventeenth-century classic, Hortus Malbaricus (1678-93), and Garcia d'Orta's sixteenth-century Conversations on the Simples, Drugs and Medicinal Substances of India (1563). The arrival of Unani in South Asia with the Delhi Sultanate, and its flourishing under the Mughal Empire, marked another and expansive process of trans-Asian medical exchanges on the subcontinent that persist to this very day. Reaching further back in time, the cosmopolitanism at issue today, in discussions about what to do with the Sanskrit medical classics in the training of vaidyas, also connects to the early centuries of the Common Era in South Asia, when and where the knowledge of itinerant physicians from South, Central, and East Asia, who belonged to Hindu and Buddhist and Jain religious traditions, was codified in the ayurvedic classics currently at our disposal. Medical cosmopolitanism in India is hardly new, in other words.

Bringing current ethnographic accounts of an old educational institution - the gurukula - to bear on our understanding of ayurvedic medical history offers heretofore unconsidered insights into the ways that practitioners of Ayurveda continue to negotiate the legacy and current experience of medical pluralism in India. In the gurukulas of central Kerala, premodern

84 Sawhney 2009, 123-24. 
Sanskrit knowledge espoused by gurus fuses with regional specializations and ayurvedic college lessons and coursework students carry with them, while new relationships with ever-changing actors (students, patients, scholars) continuously remodel the ayurvedic tradition in ways that do not necessarily rest on assimilation or refer to Western constructs. ${ }^{85}$ Where some scholars have instinctively seen ideological ossification, rigid adherence to tradition, or "pure Ayurveda" in currently active gurukulas, I suggest something different is afoot. The gurukulas I have observed have produced students who exemplify a radically new "mixed" movement within Ayurveda. They are a new generation of physicians whose commitment to being informed professionally entails the regular deployment of premodern knowledge in their contemporary practices. This knowledge is relevant to and in many ways enhances the work they go on to do after leaving the gurukula at private clinics and hospitals, as professors at ayurvedic colleges and researchers at medical labs, and sometimes as purveyors of ayurvedic tourism.

\section{Acknowledgments}

I presented an earlier version of this article at the "Indian Medicine: Between State and Village" workshop at the International Institute for Asian Studies (IIAS) in Leiden in 2016. Sita Reddy's extensive comments and suggestions on my workshop paper were vital to the revision of that initial study. Two anonymous reviewers offered generous comments and helpful suggestions to tighten and clarify the arguments presented here. I am grateful for the financial support of a Florence Tan Moeson Fellowship from the Asia Division of the Library of Congress, where I completed the writing of this article, and the expert assistance of the South Asian librarians, Jonathan Loar and Nuzhat Khatoon. Finally, many thanks go to Maarten Bode for inviting me to participate in the IIAS workshop, for pulling together this volume, and for his encouragement as transformed the original paper into this article.

\section{About the Author}

Anthony Cerulli is Associate Professor of Indian religions and medicines at the University of Wisconsin-Madison. He is the author of Somatic Lessons: Narrating Patienthood and Illness in Indian Medical Literature and co-editor

85 Diouf 2002, 114, 132. 
of The Gift in India in Theory in Practice and Medical Texts and Manuscripts in Indian Cultural History.

\section{Bibliography}

Alavi, Seema. 2008. Islam and Healing: Loss and Recovery of an Indo-Muslim Medical Tradition, 1600-1900. Basingstoke: Palgrave Macmillan.

Arnold, David. 1993. Colonizing the Body: State Medicine and Epidemic Disease in Nineteenth-Century India. Berkeley: University of California Press.

Attewell, Guy. 2014. "Compromised: Making Institutions and Indigenous Medicine in Mysore State, circa 1908-1940." Culture, Medicine, and Psychiatry 38:369-86.

Bala, Poonam. 2014. "Re-constructing' Indian Medicine: The Role of Caste in Late Nineteenth- and Twentieth-Century India." In Medicine and Colonialism: Historical Perspectives in India and South Africa, edited by Poonam Bala, 11-24. London: Pickering and Chatto.

Basu, Aparna. 1974. The Growth of Education and Political Development in India, 18981920. Delhi: Oxford University Press.

Basu, Aparna. 1982. Essays in the History of Indian Education. New Delhi. Concept Publishing.

в вС World. 2013. India Business Report: Ārya Vaidya Śāla. May 30.

Berger, Rachel. 2013. Ayurveda Made Modern: Political Histories of Indigenous Medicine in North India, 1900-1955. Basingstoke: Palgrave Macmillan.

Bode, Maarten, and Prasan Shankar. 2017. "Ayurvedic College Education, Reifying Biomedicine, and the Need for Reflexivity." Anthropology and Medicine, 114. doi: https://doi.org/10.1080/13648470.2017.1287258.

Brass, Paul. 1972. "The Politics of Ayurvedic Education: A Case Study of Revivalism and Modernization in India." In Education and Politics in India: Studies in Organization, Society, and Policy, edited by Susanne Hoeber Rudolph and Lloyd Rudolph, 342-459. Cambridge, MA: Harvard University Press.

Bureau of Education. (1920) 1965. Selections from Educational Records, Part I (1781-1839). Edited by H. Sharp. Reprint ed., Calcutta: Superintendent, Government Printing. Carakasamnhitā of Agniveśa, with the Âyurveda-Dīpikā of Cakrapānidatta. 1992. Edited by Jādavji Trikamji Āchārya. $5^{\text {th }}$ ed. New Delhi: Munshiram Manoharlal.

Central Council of Indian Medicine (СCIM). 2011-12. Prescribed Syllabus for BAMS Degree Course (Ayurvedācārya), with a List of Approved Texts \& Other Books. Varanasi: Chowkhamba Sanskrit Series Office.

Central Council of Indian Medicine (CCIM). 2015-16. New Syllabus for B.A.M.S. Course, according to the Central Council of Indian Medicine, New Delhi (along with the List of Text Books \& Other Reference Books). Compiled by Dr. Parameswarappa S. Byadgi. 
Chandra, Shailaja. 2011. "Status of Indian Medicine and Folk Healing: With a Focus on Benefits That the Systems Have Given to the Public. Pt. 1." Department of Ayurveda, Yoga and Naturopathy, Unani, Siddha, and Homoeopathy (AYUSH). New Delhi: Ramko Press.

Chattopadhyay, Anjana. 2002. Biographical Dictionary of Indian Scientists: From Ancient to Contemporary. New Delhi: Rupa.

Crawford, D. G. 1914. A History of the Indian Medical Service, 16oo-1913. Vol. 2. London: W. Thacker.

Crozier, Ralph. 1970. "Medicine, Modernization, and Cultural Crisis in China and India." Comparative Studies in Society and History 12 (3): 275-91.

Dhanvantari Malayālattile Ékavaidyamāsika. 1903-26. Edited by P. S. Varier and P. V. K. Varier. Kottakkal: Ārya Vaidya Śāla Press.

Diouf, Mamadou. 2002. "The Senegalese Murid Trade Diaspora and the Making of a Vernacular Cosmopolitanism." Translated by Steven Rendall. In Cosmopolitanism, edited by Carol A. Breckenridge, Sheldon Pollock, Homi K. Bhabha, and Dipesh Chakrabarty, 111-37. Durham, NC: Duke University Press.

Ganesan, Uma. 2010. "Medicine and Modernity: The Ayurvedic Revival Movement in India, 1885-1947." Studies on Asia 4:108-31.

Hardiman, David. 2009. "Indian Medical Indigeneity: From Nationalist Assertion to the Global Market." Social History 34 (3): 263-83.

Joseph de Saram, Amila. 2003. "Beginning the Process: The Great Masters and Selecting a Teacher: The Guru-Disciple Relationship." In The Circle of Bliss: Buddhist Meditational Art, edited by John Huntington and Diana Bangdel, 133-34. Chicago: Serindia Publications.

Krishnankutty, Gita. 2001. A Life of Healing: A Biography of Vaidyaratnam P. S. Varier. New Delhi: Viking.

Kumar, Deepak. 1997. "Unequal Contenders, Uneven Ground: Medical Encounters in British India, 1820-1920." In Western Medicine as Contested Knowledge, edited by Andrew Cunningham and Bridie Andrews, 172-90 Manchester: Manchester University Press.

Langford, Jean. 2002. Fluent Bodies: Ayurvedic Remedies for Postcolonial Imbalance. Durham, NC: Duke University Press.

Leslie, Charles. 1963. "The Rhetoric of the Ayurvedic Revival in Modern India." Man 63 (May): $72-73$.

Leslie, Charles. 1968. "The Professionalization of Ayurvedic and Unani Medicine." Transactions of the New York Academy of Sciences, ser. 2 (February): 559-72.

Leslie, Charles. 1992. "Interpretations of Illness: Syncretism in Modern Āyurveda." In Paths to Asian Medical Knowledge, edited by Charles Leslie and Allan Young. Berkeley: University of California Press.

Mazumder, N. N. 1916. A History of Education in Ancient India. New York: Macmillan. 
Mookerji, Radha Kumud. (1947) 1989. Ancient Indian Education: Brahmanical and Buddhist. Benares: Motitlal Banarsidass.

Mukharji, Projit Bihari. 2009. Nationalizing the Body: The Medical Market, Print and Daktari Medicine. London: Anthem Press.

Mukharji, Projit Bihari. 2016. Doctoring Traditions: Ayurveda, Small Technologies, and Braided Sciences. Chicago: University of Chicago Press.

Mumbai Vaidya Sabhā. 1990. Mumbai Vaidya Sabhā Shatābdi Smaranika (1890-1990). Bombay: Mumbai Vaidya Sabhā.

Mukharji, Projit Bihari. 2015. Śatakottara Rajata Jayantī Samāroha Samiti. Mumbai: Mumbai Vaidya Sabhā.

Nurullah, Syed, and J. P. Naik. 1943. A History of Education in India during the British Period. London: Macmillan.

Panikkar, K. N. 1995. "Indigenous Medicine and Cultural Hegemony." In Culture, Ideology, and Hegemony: Intellectuals and Social Consciousness in Colonial India, 145-75. New Delhi: Tulika.

Preisendanz, Karin. 2007. "The Initiation of the Medical Student in Early Classical Āyurveda: Caraka's Treatment in Context." In Pramānakirtih: Papers Dedicated to Ernst Steinkellner on the Occasion of His 7oth Birthday. Pt. 2. Edited by Birgit Kellner, Helmut Krasser, Horst Lasic, Michael T. Wieser-Much, and Helmut Tauscher, 62968. Vienna: Wiener Studien zur Tibetologie und Buddhismuskunde.

Sawhney, Simona. 2009. The Modernity of Sanskrit. Minneapolis: University of Minnesota Press.

Scharfe, Harmut. 2002. Education in Ancient India. Leiden: Brill.

Sen, Mahamahopadhyaya Kaviraj Gananath. (1911) 1940-41. Pratyaksha-Shariram. Pt. 1, A Text-Book of Human Anatomy in Sanskrit with English and Sanskrit Introductions Containing a Short History of Ayurvedic Literature. Pt. 2, A Text-Book of Human Anatomy in Sanskrit (Including History of Ayurveda). 4th ed. Calcutta: Kalpataru Press.

Sen, Mahamahopadhyaya Kaviraj Gananath. 1937. Hindu Medicine: An Address on Ayurveda Delivered at the Foundation Ceremony of Benares Hindu University in 1916. Calcutta: Kalpataru Press.

Sharma, Madhuri. 2012. Indigenous and Western Medicine in Colonial India. New Delhi: Cambridge University Press.

Sharma, Shiv. 1929. The System of Ayurveda. Bombay: Khemraj Shrikrishnadas.

Sinh Jee, H. H. Bhagvat. (1896) 1981. Aryan Medical Science: A Short History. Delhi: Rare Reprints.

Sivaramakrishnan, Kavita. 2006. Old Potions, New Bottles: Recasting Indigenous Medicine in Colonial Punjab. New Delhi: Orient Longman.

Srikanta Murthy, K. R. 1968. Luminaries of Indian Medicine. Varanasi: Chaukhambha Orientalia. 
Thatte, Dinkar Govind, and G. P. Tiwari. 1980. Current Trends in the Study of Siārīra. Varanasi: Chaukhambha Orientalia.

Udupa, Katil Narasimha, et al. 1959. Udupa Report of the Committee to Assess and Evaluate the Present Status of Ayurvedic System of Medicine. Delhi: National Printing Works.

Usman, Muhammad, et al. 1923. The Report of the Committee on the Indigenous Systems of Medicine. 2 vols. Madras.

Varier, N. V. Krishnankutty. (1980) 2002. Āyurvedacaritam. Rev. ed. Kottakkal: Ārya Vaidya Śāla.

Varier, P. S. 1916. “Āryavaidyaparișkāraṃ." Dhanvantari: Malayālattile Ēkavaidyamāsika $14(5): 108-11$.

Varier, P. S. 1942-69. Bṛhaccārīraṃ: Navīnamatānusāreṇa pracīnaśarīraśāstratatvānām vivaraṇaṃteșusandigdhatayā sampūrṇatayāvāsthitānāṃtatvānāmādhunikaśāstrā 'virodhī vistāraścās̄min suṣthu krtaḥ. 2 vols. Varanasi: Chaukhambha Sanskrit Series Office.

Varma, Daya Ram. 2015. Medicine, Healthcare, and the Raj: The Unacknowledged Legacy. Gurgaon: Three Essays Collective. 